\title{
A GENERALIZATION OF MACLAURIN'S INEQUALITIES AND ITS APPLICATIONS
}

\author{
JOSIP PEČARIĆ, JIAJIN WEN, WAN-LAN WANG AND TAO LU
}

Abstract. The well-known Maclaurin's inequalities are generalized as follows: If $x$ and $y$ are two positive $n$-tuples, and $y$ and $x / y$ are similarly ordered, then

$$
P_{n}^{[1]}(x) / P_{n}^{[1]}(y) \geqslant P_{n}^{[2]}(x) / P_{n}^{[2]}(y) \geqslant \cdots \geqslant P_{n}^{[k]}(x) / P_{n}^{[k]}(y) \geqslant \cdots \geqslant P_{n}^{[n]}(x) / P_{n}^{[n]}(y),
$$

where $P_{n}^{[k]}(a)$ is the $k$-th symmetric mean of $a$ (see[15], p. 283]). The method used in this paper is based on the computational method of descending dimension. As applications, several generalizations for the results of Izumi et al [20], Marshall and Olkin [7], Vasić et al [21], Beesack et al [22], Yang et al [5] are showed.

Mathematics subject classification (2000): 26D20, 15A45, 26D15.

Key words and phrases: symmetric mean, symmetric function, inequality, Maclauin's inequality, computational method of descending dimension, extension.

\section{REFERENCES}

[1] E. F. Bekenbach, R. Bellman, Inequalities, Springer-Verlag, Berlin, 1961.

[2] J. C. Kuang, Applied Inequalities, Hunan Education Press, 1993. (in Chinese)

[3] W.-L. WANG, P. F. WANG, A class of inequalities for the symmetric functions, Acta Math. Sinica, 27, (1984), 485-497. (in Chinese)

[4] W.-L. WANG, Some inequalities involving means and their converses, J.Math. Anal.Appl. 238, (1999), 567-579.

[5] L. YANG, J. Z. ZHANG, A class of geometric inequalities on finite points, Acta Math.Sinica, 23, (1980), 740-749. (in Chinese)

[6] L. YANG, J. Z. ZHANG, A class of geometric inequalities concerning the mass-points system, J. Chinese Univ. of Tech. Sci., 11, 2 (1981), 1-8. (in Chinese)

[7] A. W. MARShall, I. OlKIN AND F. PROSCHAN, Monotonicity of ratios of means and other applications of majorization, In Inequalities, 177-190, edited by O.Shisha, New York, London, 1967.

[8] J. J. WEN, Z. LUO, The optimal generalization of Bernoulli's inequality and its applications, J.Chengdu Univ.(Natur.Sci.), 20, 4 (2001), 1-8. (in Chinese)

[9] J. J. Wen, L.LaI AND Z.Luo, Separation of power mean by symmetric means, J. Southwest Normal College, (Natur.Sci.), 26, 3 (2000), 244-250. (in Chinese)

[10] H. N. SHI, J. J. Wen AND B. J. ZHOU, On an inequality of power means, Math. Practise and Theory, 31, 2 (2001), 227-230. (in Chinese)

[11] Z. LUO, L. LAI AND J. J. WEN, The computational method of descending dimension of global optimizations involving symmetric functions, J. Chengdu Univ.(Natur.Sci.), 21, 1 (2002), 5-11. (in Chinese)

[12] D. S. Mitrinović, J. E. PeČARIĆ AND A. M. FinK, Classical and new inequalities in analysis, Kluwer Academic Publishers, Dordrecht/Boston/London, 1993.

[13] R. Z. Zhang, J. J. Wen, The multidimensional generalization for Tutecu's conjecture, J.Sichuan Univ. (Natur.Sci.), 37, 6 (2000), 803-809. (in Chinese)

[14] Z. LUO, J. J. WEN AND H. N. SHI, A class of the geometric inequalities involving $k$-Brocard point, J. Sichuan Univ. (Natur.Sci.), 39, 6 (2002), 971-976. (in Chinese) 
[15] P. S. Bullen, D. S. Mitrinović AND P. M. Vasić, Means and their inequalities, D. Reidel Publishing Company, 1998.

[16] G. H. Hardy, J. E. LitTlewood AND G. Pólya, Inequalities, Cambridge, 2th ed. 1952.

[17] J. E. PEČARIĆ AND D. SVRTAN, Refinements of the Jensen inequalities based on samples with repetitions, J. Math. Anal. Appl., 222, (1998), 365-373.

[18] W.-L. WANG, G.-X. LI AND J. CHEN, Inequalities involving the ratios of means, J. Chendu Univ. of Tech. Sci., No. 6, (1998), 83-88,90. (in Chinese)

[19] J. J. WEN, H. N. SHI, Optimizing sharpening for Maclaurin's inequalities, J. Chengdu Univ. (Natur.Sci.), 19, 3(2000), 1-8. (in Chinese)

[20] S. IZUMI, K. KobaYAShI AND T. TAKAhashi, On some inequalities, Proc.Phys. Math.Soc., 16, 3 (1939), 345-351.

[21] P. M. VASIĆ, I. Ž. Milovanović, On the ratio of means, Univ.Beograd Publ. Elektrotehn. Fak. Mat. Fiz. No.577-598, (1977), 33-37.

[22] P. R. BeEsACK, J. E. PeČARIĆ, Integral inequalities of Čebyšev type, J. Math. Anal. Appl., 111, (1985), 643-659.

[23] D. S. Mitrinović, J. E. PeČARIĆ AND V. VOlENCE, Recent advances in geometric, inequalities, Chap. 18, Kluwer Academic Publishers, Dordrecht, 1989. 